\title{
ANALISIS TATA TULIS KARANGAN EKSPOSISI KELAS X IPS SMK MUHAMMADIYAH PONTIANAK (DITINJAU BERDASARKAN PUEBI)
}

\author{
Melia \\ Program Studi Pendidikan Bahasa dan Sastra Indonesia IKIP PGRI Pontianak, \\ Jalan Ampera Nomor 88 Pontianak \\ e-mail: melygautama@gmail.com
}

\begin{abstract}
Abstrak
Penelitian bertujuan untuk mengkaji pemakaian huruf kapital dan tanda baca yang terdapat dalam karangan eksposisi siswa kelas X IPS SMK Muhammadiyah Pontianak serta berdasarkan pengalaman peneliti ketika melihat hasil karangan sisiwa. Pertanyaan penelitian sebagai berikut: (1) Bagaimanakah pemakaian huruf kapital pada karangan eksposisi siswa kelas X IPS SMK Muhammadiyah Pontianak? dan (2) Bagaimanakah pemakaian tanda baca pada karangan eksposisi siswa kelas X IPS SMK Muhammadiyah Pontianak? Jenis penelitian adalah studi kasus. Teknik pengumpulan data yang digunakan adalah teknik studi dokumenter. Alat pengumpul data adalah dokumentasi. Teknik pemeriksaan keabsahan data menggunakan triangulasi teori. Teknik analisis data menggunakan teknik analisis model interaktif. Berdasarkan dari hasil analisis data diketahui tata tulis karangan eksposisi siswa kelas X IPS SMK Muhammadiyah Pontianak yang berjumlah 74 data masih terdapat kesalahan pemakaian huruf kapital dan pemakaian tanda baca, yaitu berupa kesalahan tanda baca titik, koma, dan tanda hubung.
\end{abstract}

Kata Kunci: tata tulis, karangan, eksposisi.

\begin{abstract}
This research was aim to examine the use of capital letters and punctuation in the exposition essay to the students of class X Muhammadiyah Vocational High School Pontianak and based on the researchers' experience readt he results of students' exposition essay. The research problems as follows: (1) How is the use of capital letters in the exposition essay to the students of class X Muhammadiyah Vocational High School Pontianak? And (2) How is the use of punctuation in the exposition essay to the students of class X Muhammadiyah Vocational High School Pontianak? This type of research was case study. The data collection technique was documentary study techniques. The tool of data collectionwas documentation. The technique of data validity was used triangulation. To analized the data used interactive model analysis techniques. Based on the results of the data analysis of the study, it was found that the procedures of writing exposition essayto the students of class X Muhammadiyah Vocational High School Pontianakwas 74 made mistake in using capital letter and punctuation, namely full stops, commas, and hyphens.
\end{abstract}

Keywords: procedure of writing, essay, exposition.

\section{PENDAHULUAN}

Menulis merupakan suatu ungkapan perasaan, gagasan, dan imajinasi seseorang yang dituangkan melalui tulisan. Menulis ialah menurunkan atau melukiskan lambang-lambang grafik yang menggambarkan suatu bahasa yang dipahami oleh seseorang sehingga orang lain dapat membaca dan memahami 
lambang-lambang grafik tersebut (Tarigan, 2013). Menulis juga diartikan sebagai bentuk kegiatan komunikasi yang disampaikan secara tidak langsung. Dalam keterampilan berbahasa terdapat empat aspek keterampilan, yaitu menyimak, berbicara, membaca, dan menulis. Dari keempat keterampilan berbahasa yang dipelajari dalam mata pelajaran Bahasa Indonesia, peneliti memilih keterampilan menulis sebagai fokus dalam penelitian.

Keterampilan menulis sangat penting bagi setiap siswa untuk dipelajari terutama pada siswa. SMK Muhammadiyah Pontianak sudah menerapkan Kurikulum 2013. Pembelajaran Kurikulum 2013 dalam materi pembelajaran Bahasa Indonesia siswa diminta untuk bisa terampil dalam membuat karya tulis ilmiah. Pembelajaran keterampilan menulis perlu memiliki banyak ide, ilmu pengetahuan, dan pengalaman hidup. Hal tersebut merupakan modal utama yang harus dimiliki dalam kegiatan menulis.

Keterampilan menulis yang dipelajari dalam mata pelajaran khususnya Bahasa Indonesia terdapat jenis karangan lainnya, yaitu karangan observasi, eksposisi, anekdot, dan cerita rakyat (hikayat). Dari keempat karangan tersebut peneliti memilih karangan eksposisi sebagai materi penelitian. Karangan eksposisi merupakan salah satu jenis karangan yang harus diperkenalkan kepada siswa dan dikuasai oleh seorang guru mata pelajaran Bahasa Indonesia. Karangan eksposisi dimaksudkan untuk memaparkan pengetahuan dan pengalaman dengan tujuan untuk menambah wawasan dan pengetahuan pembaca tentang suatu hal. Namun demikian, karangan eksposisi tidak untuk mempengaruhi pembaca, hanya memaparkan pengetahuan saja agar wawasan pembaca tentang suatu hal dapat bertambah.

Hal yang perlu diperhatikan dalam suatu karya tulis ilmiah adalah penggunaan tata tulis dengan berpedoman pada Pedoman Umum Ejaan Bahasa Indonesia (PUEBI). Hal tersebut menjadikan hasil sebuah tulisan yang tidak hanya memiliki nilai estetika tetapi juga berkualitas. Seperti yang diketahui, dalam membuat tulisan yang bermutu sebagai pengguna bahasa diharuskan untuk mematuhi dan mengikuti kaidah bahasa Indonesia yang berlaku, yaitu PUEBI. 
Pengajaran keterampilan menulis di SMK Muhammadiyah Pontianak tidaklah mudah karena hanya sebagian siswa yang menguasai secara optimal aspek-aspek dalam menulis. Keterampilan menulis yang tidak diimbangi dengan pemahaman menjadi salah satu faktor kurang terampilnya siswa dalam menulis. Perlu adanya analisis lebih mendalam terkait keterampilan siswa dalam menulis karangan. Hal tersebut penting untuk dilaksakan agar siswa memiliki keterampilan dalam menulis, khususnya dalam menulis karangan eksposisi.

Implementasi dalam pendidikan ditingkat SMA khususnya materi teks eksposisi diajarkan pada siswa SMA/SMK kelas X semester ganjil Kurikulum 2013 tercakup dalam Kompetensi Dasar (KD) 3.4 yaitu menganalisis struktur dan kebahasaan teks eksposisi dalam kegiatan pembelajaran siswa diminta untuk membuat keterampilan yaitu praktik menulis teks eksposisi dengan memerhatikan isi (permasalahan, argumen, pengetahuan, dan rekomendasi), struktur, dan kebahasaan.

Pemilihan tata tulis dalam penelitian dikarenakan: pertama, dalam penulisan siswa masih terdapat kesalahan khususnya dalam pembuatan karya tulis ilmiah. Kedua, kurangnya pemahaman mengenai tata tulis dan ketidaktepatan siswa dalam penggunaan ejaan. Ketiga, peneliti ingin memberikan pengajaran tentang cara penggunaan tata tulis yang baik dan benar.

Karangan eksposisi sebagai materi dalam penelitian adalah karangan eksposisi merupakan salah satu jenis karangan yang harus diperkenalkan kepada siswa dan dikuasai oleh seorang guru mata pelajaran Bahasa Indonesia. Karangan dimaksud untuk memaparkan pengetahuan dan pengalaman dengan tujuan untuk menambah wawasan dan pengetahuan pembaca tentang suatu hal. Dengan mengambil materi karangan eksposisi, peneliti meyakini siswa akan lebih mampu menyampaikan, mengungkapkan, menerangkan atau menguraikan suatu gagasan berupa pokok-pokok pemikiran mengenai suatu topik yang sifatnya non-fiksi dengan dasar argumentasi yang kuat.

Eksposisi adalah suatu bentuk tulisan atau retorika yang berusaha untuk menerangkan dan menguraikan suatu pokok pikiran yang dapat memperluas pandangan atau pengetahuan pembaca. Dalam karangan eksposisi, penulis tidak 
berusaha mempengaruhi pendapat pembaca, setiap pembaca boleh menolak atau menerima apa yang dikemukakan oleh penulis (Keraf, 1982).

Siswa-siswi kelas X IPS SMK Muhammadiya Pontianak dipilih menjadi objek penelitian karena sebelumnya peneliti telah melakukan praobservasi kelas dari jumlah kelas X yang hanya terdiri dari satu kelas saja yaitu kelas X IPS. Oleh karenanya, kelas X IPS menjadi objek penelitian dalam melakukan penelitian guna memberikan pemahaman tentang pemakaian huruf kapital dan pemakaian tanda baca yang disesuaikan berdasarkan PUEBI yang berlaku.

Pemilihan penelitian studi kasus dikarenakan: pertama, peneliti menemukan permasalahan yang ada pada siswa SMK Muhammadiyah Pontianak khususnya dalam proses praktik membuat suatu keterampilan menulis. Kedua, peneliti ingin membantu menyelesaikan permasalahan yang dialami oleh siswa. Peneliti memilih penelitian studi kasus dan bukan penelitian lainnya karena dari penelitian studi kasus terdapat keunikan atau keunggulan tersendiri dalam penelitian sosial. Secara umum studi kasus memberikan akses atau peluang yang luas kepada peneliti untuk menelaah secara mendalam, detail, intensif, dan menyeluruh terhadap unit sosial yang diteliti.

Penelitian yang dilakukan oleh Satini (2016) menganalisis hasil karangan eksposisi yaitu kesalahan tata tulis pemakaian huruf dan penggunaan tanda baca. Perbedaan penelitian adalah pada metode penelitiannya, yaitu penelitiannya menggunakan metode Penelitian Tindakan Kelas. Berdasarkan paparan tersebut, peneliti telah menguraikan mengenai keterampilan menulis, tata tulis, karangan eksposisi serta terdapat beberapa alasan yang mendasari peneliti melakukan penelitian.

\section{METODE}

Metode yang digunakan dalam penelitian adalah metode deskriptif, yaitu mendeskripsikan pemakaian huruf kapital dan pemakaian tanda baca yang terdapat dalam penggunaan tata tulis pada karangan ekposisi kelas X IPS SMK Muhammadiyah Pontianak. Sumber data yang digunakan dalam penelitian adalah siswa-siswi kelas X IPS yang berjumlah 31 orang dengan menggunakan teknik 
simple ramdom sampling. Data yang digunakan dalam penelitian adalah kata-kata, frasa, kalimat yang menujukkan pemakaian huruf kapital dan pemakaian tanda baca. Data yang digunakan dalam penelitian berupa hasil karangan eksposisi kelas X IPS SMK Muhammadiyah Pontianak.

Teknik pengumpulan data yang digunakan adalah teknik studi dokumenter. Alat pengumpul data yang digunakan adalah dokumentasi dengan alat penunjang dalam dokumentasi ialah kamera dan buku catatan lapangan. Teknik pemeriksaan keabsahan data menggunakan triangulasi teori. Peneliti memanfaatkan teori yang digunakan dalam penelitian, yaitu peneliti membandingkan data yang diperoleh dengan beberapa teori yang ada serta melakukan analisis secara mendalam dan mengecek validitas data dengan menyesuaikan teori yang digunakan dalam penelitian. Teknik analisis data dalam penelitian menggunakan teknik analisis model interaktif.

\section{HASIL DAN PEMBAHASAN}

Hasil penelitian akan dibahas terkait dengan pemakaian huruf kapital dan pemakaian tanda baca pada karangan eksposisi kelas X IPS SMK Muhammadiyah Pontianak. Penggunaan huruf kapital atau huruf besar dipakai sebagai huruf pertama kata awal kalimat. Berikut hasil karangan yang ditulis oleh Febriani yang berjudul Lingkungan Sekolah yang Bersih, temuan datanya yaitu "Sekolah yang bersih adalah lingkungan yang bebas dari Kotoran". Kesalahan yang dilakukan yaitu terdapat pemakaian huruf kapital di akhir kalimat pada kata Kotoran huruf pertama $\underline{K}$ seharusnya ditulis menggunakan huruf kecil. Berdasarkan PUEBI 2017 pemakaian huruf kapital tidak dipakai sebagai huruf pertama kata pada akhir kalimat. Penulisan yang benar adalah Sekolah yang bersih adalah lingkungan yang bebas dari kotoran.

Permasalahan yang kedua adalah pemakaian tanda baca pada karangan eksposisi siswa. Tanda baca merupakan simbol yang tidak berhubungan dengan fonem, kata, dan frasa pada suatu bahasa melainkan berperan untuk menunjukkan struktur dan organisasi suatu tulisan, intonasi, serta jeda yang dapat diamati sewaktu pembacaan (Achmad, 2015). Pemakaian tanda baca menurut 
Setyaningrum (2013) membedakan atas pemakaian tanda titik, tanda koma, tanda hubung, tanda tanya, tanda seru.

Berikut hasil tanda titik (.) untuk karangan yang ditulis oleh Budi Sentoso yang berjudul Menjaga Keindahan Lingkungan Alam. Temuan datanya yaitu paragraf pertama kalimat kedua, "Jenis lainnya antara lain lingkungan rumah yang bisa dikenal dengan Lingkungan keluarga dan lingkungan sekolah". Analisis datanya yaitu kesalahan yang dilakukan adalah tidak menggunakan tanda baca titik di akhir kalimat. Seharusnya disetiap penulisan akhir kalimat diberikan tanda titik. Berdasarkan PUEBI 2017 tanda titik dipakai pada akhir kalimat yang bukan pertanyaan atau seruan. Penulisan yang benar adalah Jenis lainnya antara lain lingkungan rumah yang bisa dikenal dengan Lingkungan keluarga dan lingkungan sekolah.

Berikut hasil pemakaian tanda koma (,) untuk karangan yang ditulis oleh Kusuma Wardani yang berjudul tentang Lingkungan. Temuan datanya yaitu paragraf kedua kalimat pertama "Namun, masih banyak siswa yang kurang menjaga kebersihan sekolah". Kesalahan yang dilakukan yaitu pada pemakaian tanda koma yang berada di awal paragraf yaitu pada kata Namun, seharusnya di belakang kata tidak diberikan tanda koma. Berdasarkan PUEBI 2017 tanda koma tidak dipakai dibelakang kata atau ungkapan penghubung antarkalimat yang terdapat di awal paragraf. Sehingga ditulis menjadi Namun masih banyak siswa yang kurang menjaga kebersihan sekolah.

Berikut hasil pemakaian tanda hubung (-) yang ditulis oleh Kusuma Wardani yang berjudul tentang lingkungan sekolah. Temuan datanya yaitu Paragraf ketiga kalimat keempat "Kurang kesadaran akan kebersihan dan malas itulah penyakit siswa siswi”. Analisis datanya yaitu Kesalahan yang dilakukan pada kata "siswa siswi" yaitu terdapat kata ulang namun penulisannya tidak menggunakan tanda hubung, seharusnya disetiap kata ulang atau reduplikasi ditulis menggunakan tanda hubung. Berdasarkan PUEBI 2017 tanda hubung digunakan untuk menyambung unsur-unsur kata ulang. Sehingga penulisan yang benar adalah Kurang kesadaran akan kebersihan dan malas itulah penyakit siswasiswi. 
Dari hasil temuan penelitian yang dibahas, peneliti dapat memaparkan bahwa siswa lebih cenderung melakukan kesalahan berbahasa yaitu pada penulisan pemakaian huruf kapital. Adapun data keseluruhan yang diperoleh berjumlah tujuh puluh empat data yaitu lima puluh delapan data kesalahan pemakaian huruf kapital dan enam belas data kesalahan pemakaian tanda baca yang terdiri dari kesalahan tanda baca titik, tanda koma, dan tanda hubung. Pada hasil penelitian, peneliti memasukkan dua data saja sampel sebagai contoh, tetapi keseluruhan data yang sebenarnya berjumlah 31 data.

\section{SIMPULAN}

Berdasarkan analisis data mengenai tata tulis karangan ekposisi kelas X IPS SMK Muhammadiyah Pontianak dapat disimpulkan bahwa pemakaian huruf kapital dan tanda baca pada Karangan Eksposisi Kelas X IPS SMK Muhammadiyah Pontianak dikategorikan cukup baik. Dari hasil temuan masalah penelitian yang dibahas, peneliti dapat memaparkan bahwa siswa lebih cenderung melakukan kesalahan berbahasa yaitu pada penulisan pemakaian huruf kapital. Adapun data keseluruhan yang diperoleh berjumlah tujuh puluh empat data yaitu lima puluh delapan data kesalahan pemakaian huruf kapital dan enam belas data kesalahan pemakaian tanda baca yang terdiri dari kesalahan tanda baca titik, tanda koma, dan tanda hubung.

\section{DAFTAR PUSTAKA}

Achmad, S. W. 2015. Buku Induk Mahir Bahasa dan Sastra Indonesia Pedoman Praktis Menulis dalam Bahasa Indonesia. Yogyakarta: Araska.

Bungin, B. 2005. Analisis Data Penelitian Kualitatif. Jakarta: PT Raja Grafindo Persada.

Chaer, A. 2011. Tata Bahasa Praktis Bahasa Indonesia. Jakarta: Rineka Cipta.

Dalman. 2016. Keterampilan Menulis. Jakarta: PT. Raja Grafindo Persada.

Darmadi, H. 2011. Metode Penelitian Pendidikan. Bandung: Alfabeta.

Finoza, L. 2009. Komposisi Bahasa Indonesia. Jakarta: Diksi Insan Mulia.

Keraf, G. 1982. Eksposisi dan Deskripsi. Ende-Flores: Nusa Indah.

Kosasih. 2014. Jenis-jenis Teks. Bandung: Yarma Widya.

Moleong, L. J. 2012. Metodologi Penelitian Kualitatif. Bandung: PT Remaja Rosdakarya. 
Mustikowati, D., dkk. 2016. Meningkatkan Semangat Membaca dan Menulis Siswa Sekolah Dasar dengan Permainan Kata Bersambut. Jurnal Riset dan Konseptual, 1(1): 39-42.

Nasucha ,Y., dkk. 2012. Bahasa Indonesia untuk Penulisan Karya Tulis Ilmiah. Surakarta: Media Perkasa.

Nawawi, H. 2012. Metode Penelitiam Bidang Sosial. Yogyakarta: Gadjah Mada University Press.

Press, T. P. 201). Pedoman Umum Ejaan Bahasa Indonesia. Jakarta: Permata Press.

Rohmadi, M., dkk. 2013. Belajar Bahasa Indonesia. Surakarta: Cakrawala Media.

Ratna, K. N. 2015. Teori, Metode, dan Teknik Penelitian Sastra. Yogyakarta: Pustaka Belajar.

Satini, R. 2016. Kemampuan Menulis Karangan Eksposisi dengan Menggunakan Teknik Mind Map Siswa Kelas X SMA Negeri 14 Padang. Jurnal Gramatika, 2(2): 164-178.

Subana \& Sudrajat. 2009. Dasar-Dasar Penelitian Ilmiah. Bandung : CV Pusaka Setia.

Setia, P. 2017. Pedoman Umum Ejaan Bahasa Indonesia yang Disempurnakan dan Pedoman Umum Pembentukan Istilah. Bandung: CV Pustaka Setia.

Setyaningrum, W. 2013. Rangkuman Materi Bahasa Indonesia. Jogjakarta: PT Buku Kita.

Sugiyono. 2017. Metode Penelitian Pendidikan. Bandung: Alfabeta.

Tarigan, H. G. 2013. Menulis Sebagai Suatu Keterampilan Berbahasa. Bandung: Angkasa.

Zuldafrial \& Lahir, M. 2012. Penelitian kualitatif. Surakarta: Yuma Pustaka. Zuldafrial. 201). Penelitian Kualitatif. Pontianak: STAIN Pontianak Press. 